\title{
DIFFERENTIATED LEARNING AS A MEANS OF INDIVIDUALIZATION OF THE STUDY PROCESS IN THE COURSE OF FOREIGN LANGUAGE TRAINING AT A TECHNICAL UNIVERSITY
}

The article concerns ways of individualization of the study process through differentiated learning technologies in the course of foreign language training at a higher technical educational establishment. According to the humanistic concept of the contemporary higher education, the latter ought to be learner-centered, it allowing meeting fully both learner's educational and individual psychological needs. That determines development of learning packs, selection of teaching methods and study process organization forms.

The article presents the analysis of specific organizational features of the study process based on differentiation. It describes two forms of differentiation commonly used - internal and external ones depending on either heterogeneous or homogeneous groups of students. The purpose in both cases is to take into careful account abilities and needs of the learner.

There is a detailed description of an external differentiation pattern successfully implemented in the course of a project in intensive English teaching at the Faculty of Information Technology. Within this differentiation approach, homogeneous groups of students are formed (from the «least able» to «most able» ones) according to students' initial foreign language competence level and following the principle of relative stability. The letter means a possibility for a student to be transferred to another group in order to match his or her actual development of speech skills.

The selected differentiation pattern appeared to be justified because it takes into account non-linguistic students' profile, characterized by the great diversity of students' foreign language competence and learning motivation.

The article describes basic conditions for effective realization of the above form of differentiation: regular monitoring of the actual foreign language competence level with due regard to student self-assessment and survey; creation of a comfortable learning environment in class by means of maintaining parity among all the participants of the study process; application of interactive teaching methods; proper coordination of the teaching staff.

Key words: communicative competence, differentiation form, learning environment, teaching method, level differentiation, homogeneous/ heterogeneous groups.

Introduction. The growing role of a foreign language as one of the basic general education disciplines in the system of professional training of specialists at a higher technical school puts forward a wide range of tasks related to the practical implementation of modern approaches to teaching a foreign language, such as task-based, situational, communicative, interactive, differentiated and others.

These approaches are consistent with the humanistic concept that underlies modern innovative teaching, which puts the learner personality at the forefront, taking into account their individual psychological characteristics, and, accordingly, creating conditions for the best possible realization of their personal potentials.

One of the effective ways to individualize the learning process in a higher school environment, in our opinion, is the use of differentiated learning technologies. On the one hand, these technologies help to overcome difficulties that often arise due to differences in the initial level of students' foreign language competence at the beginning of university education; and, on the other hand, they contribute to the sustainable formation and growth of individual communicative skills of students who are trained in groups.

Analysis of recent investigations and publications. Differentiation as a principle of organizing the educational process originated in the mass school in the 19th century. Since then, obviously, the principles and forms of differentiated learning have repeatedly changed in accordance with the concept of education existing at different stages of society development.

The modern concept of education is based on the idea that readiness for future activity is an internal need of the individual and cannot be completely determined from the outside. Consequently, the main 
task of the university is to provide services that are to meet the educational needs of the individual [1].

To achieve this goal educators are supposed to create certain conditions of the educational environment, which make the maximum development of the student potential possible. In this context, domestic and foreign scientists consider differentiated learning as an effective means of creating such a productive educational environment that takes into account psychological characteristics of the individual [2].

The methodology of the modern concept of a differentiated approach is based primarily on the works in the field of personality psychology by S. Rubenstein, K. Platonov, B. Ananyev, A. Leontiev, P. Galperin and others, systemic differentiation and individualization of the educational and pedagogical process of I. Unt, H. Liimets, C. Washburne, A. Kirsanov, Yu. Babansky, the role of educational motivation by $L$. Bozhovich, T. Shamova, G. Shchukin and others, as well as on L. Vygotsky's theory of the zone of proximal development. Studies on the developing potential of a foreign language by I. Bim, N. Gez, I. Zimnyaya, G. Kitaigorodskaya, E. Passov, etc made a great contribution to the formation of the concept of differentiated learning, the latter being considered as a tool for building professional foreign language competence.

Pointing out issues requiring further investigation. However, many aspects of the practical implementation of the principles of differentiated learning at a higher technical school, in particular in relation to teaching a foreign language, need further investigation. These include the following: interaction of the teaching staff under conditions of differentiated learning; organization of study process in relatively stable groups that admit the possibility for any student to change their group within the created hierarchy of groups depending on the student actual level of foreign language competence; preferable teaching methods applied under conditions of level differentiation, and others.

The objective of the article. The article summarizes the experience of application of differentiated learning technologies in foreign language classes within the framework of a project in intensive English teaching of first-year IT students, considers basic requirements that are of importance for successful implementation of differentiated learning.

Presentation of the main research material. Differentiated learning is understood to be, on the one hand, creation of various learning conditions in order to take into account characteristics of learners and, on the other, a complex of methodological, psychological, pedagogical and organizational measures that provide learning in homogeneous groups [3].

It is customary to distinguish between «internal» and «external» differentiation. Internal differentiation implies such an organization of the educational process, which takes into account individual charac- teristics of the student in a heterogeneous / mixed group. A common form of internal differentiation is level differentiation, which allows a student to master educational material, skills within one of the levels defined by the syllabus (not lower than the basic one) in accordance with their abilities and individual needs [4]. With external differentiation, relatively homogeneous groups of students are formed with the same goal of achieving maximum individualization of the learning process. In other words, the objective of differentiation is to educate each student at a level that matches his or her abilities and interests. Once the teacher is aware of the actual level of his or her students' foreign language skills and knowledge of the subject, he or she determines their zone of proximal development and, using a diverse range of teaching methods at hand, brings them to a higher level.

It is important to understand that differentiation consists not only in grouping students according to their inborn abilities and initial level of communicative language competence, but also naturally implies the differentiation of the content of education as well as forms and types of student classroom or independent work.

Let us consider the above-mentioned theoretical provisions giving an example of the implementation of a project in intensive English teaching of first-year bachelors of the Faculty of Information Technology. The project has been under successful implementation for eight years at the Department of Foreign Languages of Pryazovskyi State Technical University. The goal of the project was to form a high level of students' foreign language competence, which would allow them to actively participate in international programs and events, listen to lectures on professional subjects in English, be engaged in scientific work, etc. Accordingly, the task was to achieve a level of language proficiency in the main types of speech activities not lower than B1+ / B2 within the Common European Standards. The department created a learning pack based on textbooks published by Oxford University Press; the priority teaching methods used were interactive one, as they tend to create the most active learning environment, simulating in some degree the forms of real communication, where the student as an educational process party acquires maximum subjectivity, reveals their creative potential [5].

It is worth mentioning that the choice of first-year students as the target group was determined by the following factors. Firstly, for students the first year is a period of their adaptation to the new academic environment, and in this case, they are best susceptible to purposeful psychological and pedagogical influence and demonstrate an optimum development of their sensory and perceptual, mnemonic, psychomotor and especially speech-thinking functions [6]. Secondly, big differences in the initial level of for- 
eign language competence of first-year students in non-linguistic universities has become a common problem, and that can be effectively solved by means of differentiated learning among other things.

The results of the entry test in English, which is traditionally held before the start of the course among first-year technical students, have shown in recent years a steady tendency for three-level gradation of students' foreign language competence within the Common European Framework of Reference for Languages: Elementary (A1-2), Pre-Intermediate $(A 2, B 1)$ and Intermediate $(B 1+)$. Therefore, the study groups were formed according to three levels. The distribution of students by levels at the initial stage in percentage terms was the following: Elementary $20 \%$, Pre-Intermediate $-70 \%$, Intermediate - $10 \%$. The fundamental point in the level differentiation of study groups was their further gradation within the level to "stronger /less strong" ones. The main principle of grouping students, that helped to ensure flexibility and adaptability of the group hierarchy regarding the dynamics of development of each student foreign language competence, was the possibility for a student to move from group to group during a term. The students could move to another group within his or her own level or to a group of a higher /lower level according to their academic performance during the term (based on intermediate results). This form of group formation, on the one hand, motivates the student for active development, stimulates his or her desire to move to a higher-level group, on the other hand, allows the teacher to select the pace, forms and types of learning activities that best meet the needs of a particular student group.

The decision to transfer a student to a higher or lower-level group was always preceded by a thorough analysis of his or her current performance, student reports on self-assessment of the dynamics of the development of their speech activity skills, educational motivation, psychological compatibility in the group, etc.

Traditional survey at the end of the course among the IT students involved in the project showed that as high as $88 \%$ (the average percentage for the entire period of the project implementation) approve of the level principle of group formation with the possibility of transfer [2]. At the same time, this system of student differentiation into groups that are relatively homogeneous took a favorable view by the teachers of the department, since the system facilitated preparation for classes, boosted the process of mastering the material by learners, and created an atmosphere of success in class. Besides, the possibility of being transferred both "down" and "up" the hierarchy prevented the manifestation of a number of negative aspects of differentiation, which are widely discussed in the methodological literature [7] (for example, snobbery among strong students or inferiority feel- ings among weak students), since it encouraged each student to learn with utmost diligence.

The key condition for the successful implementation of the described form of differentiation in the course of teaching a foreign language, in the author's opinion, is building a new work style by the teaching staff - well-coordinated teamwork, when everyone works being aware of increased personal responsibility for the results of a common cause. Therefore, teachers tend to take creative initiative, give support and mutual assistance, and openly discuss responsible decisions in the workplace. At the department, from the very beginning of the project, an initiative group of teachers was made up, overseeing various issues of educational, methodological, technical and organizational support; the rule of turnover of the project coordinator being implemented. The employed teamwork routine also made it possible to maintain uniform assessment criteria, avoiding overestimation or underestimation that might erode the multilevel differentiation.

When applying the term of "homogeneity" to describe a study group, it is necessary to emphasize the relativity of this notion, since in practice students do not always show identical performance, foreign language speech skills, personal characteristics, behavioral styles, motivational attitudes, etc. Therefore, the comfort of working with the class for a teacher in such conditions should be viewed as an opportunity to use appropriately different forms and types of teaching methods at hand, an opportunity to experiment.

For the department, the project in intensive English teaching became experimental not only in terms of a new approach to the formation of study groups, but also made it possible to widely experiment with interactive learning in the classroom. One must admit that differentiation helps to create favorable conditions for effective implementation of interactive approach in the educational process. Since interactive learning relies on students' interaction in performing tasks that simulate various forms of real communication, and aims at unleashing the creative potential of each participant in the process of self-actualization and self-realization [5], the selection of students in an academic group plays a significant role.

The students involved in the project represented all the departments of the Faculty of Information Technologies, and thanks to the differentiation scheme, they might happen to study in the same class. That mixture of the student body and productive interaction in class contributed to establishing cooperative relationships among students of the faculty throughout the training period. At the same time, on the organization level, this students' mixture required some adjustment in groups' timetables and issuing additional student record sheets for each department of the faculty. 
When coordinating interpersonal interaction in a group, the primary task for the teacher was to create a positive and productive atmosphere in the classroom, to establish informal and equal relationships based on mutual support and approval. The authoritarian style of interaction between the teacher and the student gave way to a parity style, which was appreciated by both students and teachers [8, c.34].

In the end, it should be emphasized that differentiation of the student body according to their current level of foreign language competence does not exclude the use of various forms and types of differentiated learning activities in class and extracurricular / independent work within relatively homogeneous groups. One should always bear in mind that the major principle of individualization is taking into account a wide range of learner's individual characteristics, of which the level of foreign language competence is very important though not the only one.

Conclusions. The analysis of the differentiation applied in the project showed that the effectiveness of this approach depends on the following: thorough evaluation of students' entry test results, student self-assessment, diagnostic student survey at all stages of training; the formation of groups with possibility of student transfer according to the results of current academic performance; team mentality of the teaching staff; building a psychologically favorable, creative learning environment by means of interactive learning methods. If properly used, this differentiation form ought to become an effective means of implementing a learner-centered approach for foreign language training at a higher technical school.

\section{References:}

1. Николаев Е.И. Дифрференциация как педагогическая технология повышения интереса к знаниям: на примере обучения иностранному языку в неязыковом вузе : авторефр. дис. ... канд. пед. наук :13.00.01. Якутск, 2005. 15 с.

2. Лазаренко Л.М., Барабаш І.В. Застосування інтерактивних методів навчання при формуванні іншомовної комунікативної компетенції у студентів немовних спеціальностей. Науковий вісник Міжнародного гуманітарного університету. Серія «Філологія». 2017. № 2(31) C. 154-156.

3. Селевко Г.К. Современные образовательные технологии : учебное пособие. Москва : Народное образование, 2008. 200 с.

4. Зайцева И.А. Технология уровневой дифрференциации как средство формирования профессиональной иноязычной коммуникативной компетенции студентов технического вуза : автореф. дис. ... канд. пед. наук: 13.00.08. Самара, 2007. 24 c.

5. Лазаренко Л.М. Педагогічні умови використання активних методів навчання у процесі формування профресійної іншомовної компетентності бакалаврів. Молодь і ринок. 2018. № 3(158). C. 63-68. DOI: https://doi. org/10.24919/2308-4634.2018.128970.

6. Ананьев Б.Г. Психофризиология студенческого возраста и усвоения знаний. Вестник высшей школы. 1972. № 7.46 с.

7. Тусулбекова М.Ж. Проблемы организации индивидуально-диффреренцированного подхода обучения английскому языку студентов неязыковых специальностей в теории и практике. Молодой ученый. 2009. № 3(3). C. 195-201. URL: https://moluch.ru/archive/3/216/ (дата обращения: 03.01.2021).

8. Інтерактивні технології: теорія та методика : посібник / О.І. Пометун та ін. Умань ; Київ, 2008. 94 с.

Барабаш І. В. Диференційоване навчання як засіб індивідуалізації навчального процесу під час викладання іноземної мови в технічному університеті

Статтю присвячено способам індивідуалізації навчального процесу через застосування диференційованого навчання під час викладання іноземної мови в умовах вищої технічної школи. Зважаючи на гуманістичну концепцію сучасної вищої освіти, навчання повинно мати особистісно-орієнтований характер, що дає змогу забезпечувати найбільш повне задоволення як навчальних, так і індивідуально-психологічних потреб здобувача. Це знаходить відображення в розробленні навчально-методичних комплексів, виборі методичних прийомів і формах організації навчального процесу.

У статті представлено аналіз специфріки організації навчального процесу із застосуванням диференційованого навчання. Дано опис двох видів навчальної дифреренціації, які практикуються: зовнішньої і внутрішньої, пов'язаних із формуванням гетерогенних або гомогенних груп учнів. В обох випадках за мету ставиться максимальне врахування індивідуальних можливостей і потреб особистості здобувача.

Детально описано модель зовнішньої диференціації навчання, яка була успішно застосована у проєкті з поглибленого вивчення англійської мови на факультеті інформаційних технологій. Ця модель дифреренціації передбачає створення гомогенних навчальних груп (від більш "слабких» до більш «сильних») на основі вхідного рівня іншомовної компетенції студентів за принципом відносної стабільності. Останній допускає можливість переходу студента в іншу групу, зважаючи на актуальні показники розвитку мовленнєвих навичок і умінь.

Обгрунтовано вибір цього виду дифреренціації, що враховує специфріку студентського контингенту немовного вишу, якому властива значна неоднорідність складу в плані іншомовної підготовки і мотивації. 
Розглянуто базові умови ефрективної роботи запропонованої моделі, такі як постійний моніторинг поточних показників рівня іншомовної компетенції студентів, у тому числі фрормами самоконтролю, анкетування студентів, створення психологічно коморортних умов в аудиторії за рахунок установлення паритетних взаємовідносин між усіма учасниками навчального процесу, використання інтерактивних технологій навчання, злагоджена взаємодія педагогічного колективу.

Ключові слова: комунікативна компетенція, форма диференціації, учбове середовище, метод викладання, рівнева диференціація, однорідна/неоднорідна група. 